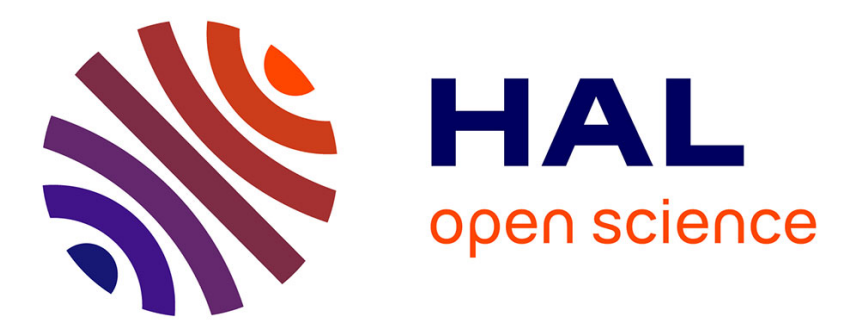

\title{
Air conditioning using an air-cooled single effect lithium bromide absorption chiller: results of a trial conducted in Madrid in August 2005
}

\author{
M. Izquierdo, R. Lizarte, J.D. Marcos, G. Gutiérrez
}

\section{- To cite this version:}

M. Izquierdo, R. Lizarte, J.D. Marcos, G. Gutiérrez. Air conditioning using an air-cooled single effect lithium bromide absorption chiller: results of a trial conducted in Madrid in August 2005. Applied Thermal Engineering, 2008, 28 (8-9), pp.1074. 10.1016/j.applthermaleng.2007.06.009 . hal-00498956

\section{HAL Id: hal-00498956 https://hal.science/hal-00498956}

Submitted on 9 Jul 2010

HAL is a multi-disciplinary open access archive for the deposit and dissemination of scientific research documents, whether they are published or not. The documents may come from teaching and research institutions in France or abroad, or from public or private research centers.
L'archive ouverte pluridisciplinaire HAL, est destinée au dépôt et à la diffusion de documents scientifiques de niveau recherche, publiés ou non, émanant des établissements d'enseignement et de recherche français ou étrangers, des laboratoires publics ou privés. 


\section{Accepted Manuscript}

Air conditioning using an air-cooled single effect lithium bromide absorption chiller: results of a trial conducted in Madrid in August 2005

M. Izquierdo, R. Lizarte, J.D. Marcos, G. Gutiérrez

PII:

S1359-4311(07)00209-8

DOI:

10.1016/j.applthermaleng.2007.06.009

Reference:

ATE 2198

To appear in:

Applied Thermal Engineering

\section{APPLIED}

THERMAL

ENGINEERING

27 February 2007

Received Date:

11 June 2007

Revised Date:

Accepted Date: $\quad 16$ June 2007

Please cite this article as: M. Izquierdo, R. Lizarte, J.D. Marcos, G. Gutiérrez, Air conditioning using an air-cooled single effect lithium bromide absorption chiller: results of a trial conducted in Madrid in August 2005, Applied Thermal Engineering (2007), doi: 10.1016/j.applthermaleng.2007.06.009

This is a PDF file of an unedited manuscript that has been accepted for publication. As a service to our customers we are providing this early version of the manuscript. The manuscript will undergo copyediting, typesetting, and review of the resulting proof before it is published in its final form. Please note that during the production process errors may be discovered which could affect the content, and all legal disclaimers that apply to the journal pertain. 
Air conditioning using an air-cooled single effect lithium bromide absorption chiller: results of a trial conducted in Madrid in August 2005

\section{Izquierdo ${ }^{\text {* }}$, R. Lizarte ${ }^{\mathrm{b}}$, J.D. Marcos ${ }^{\mathrm{c}}$, G. Gutiérrez ${ }^{\mathrm{b}}$}

${ }^{a}$ Instituto de Ciencias de la Construcción Eduardo Torroja (CSIC) c/Serrano Galvache 4, 28033 Madrid, Spain.

${ }^{\mathrm{b}}$ Universidad Carlos III de Madrid, Escuela Politécnica Superior, Avenida de la Universidad 30, 28911, Leganés, Madrid, Spain.

${ }^{c}$ Escuela Técnica Superior Ingeniería Industrial, UNED, c/Juan del Rosal 12, 28040 Madrid, Spain.

Unidad Asociada de Ingeniería Térmica y Fluidos CSIC-UC3M

\section{Abstract}

Trials were conducted to determine the performance of a commercial (Rotartica 045v) 4.5-kW air-cooled, single effect $\mathrm{LiBr} / \mathrm{H}_{2} \mathrm{O}$ absorption chiller for residential use. The experiments were run at La Poveda, Arganda del Rey, Madrid, in August 2005.Three typical August days, with different outdoor temperatures, were chosen for the study. The hot water inlet temperature in the generator varied throughout the day from $80^{\circ} \mathrm{C}$ to $107^{\circ} \mathrm{C}$. Thermal demand was calculated, along with period energy balance and COP. Variations in machine component temperatures were recorded and chilling power and the daily COP calculated for each of the three days. The results for the period as a whole showed that cooling power tended to decline with rising outdoor dry bulb temperatures. At temperatures from 35 to $41.3^{\circ} \mathrm{C}$ the chilled water outlet temperature

\footnotetext{
* Corresponding author. Tel.: + 349187132 48; fax: + 34918713248 E-mail address: mizquierdo@ietcc.csic.es (M.Izquierdo)
} 
in the evaporator climbed to over $15^{\circ} \mathrm{C}$. The average $\mathrm{COP}$ for the period, when auxiliary equipment was included into the calculations, was 0.37 .

Keywords: absorption, LiBr-water, single effect, air-cooled, Rotartica

\section{Nomenclature}

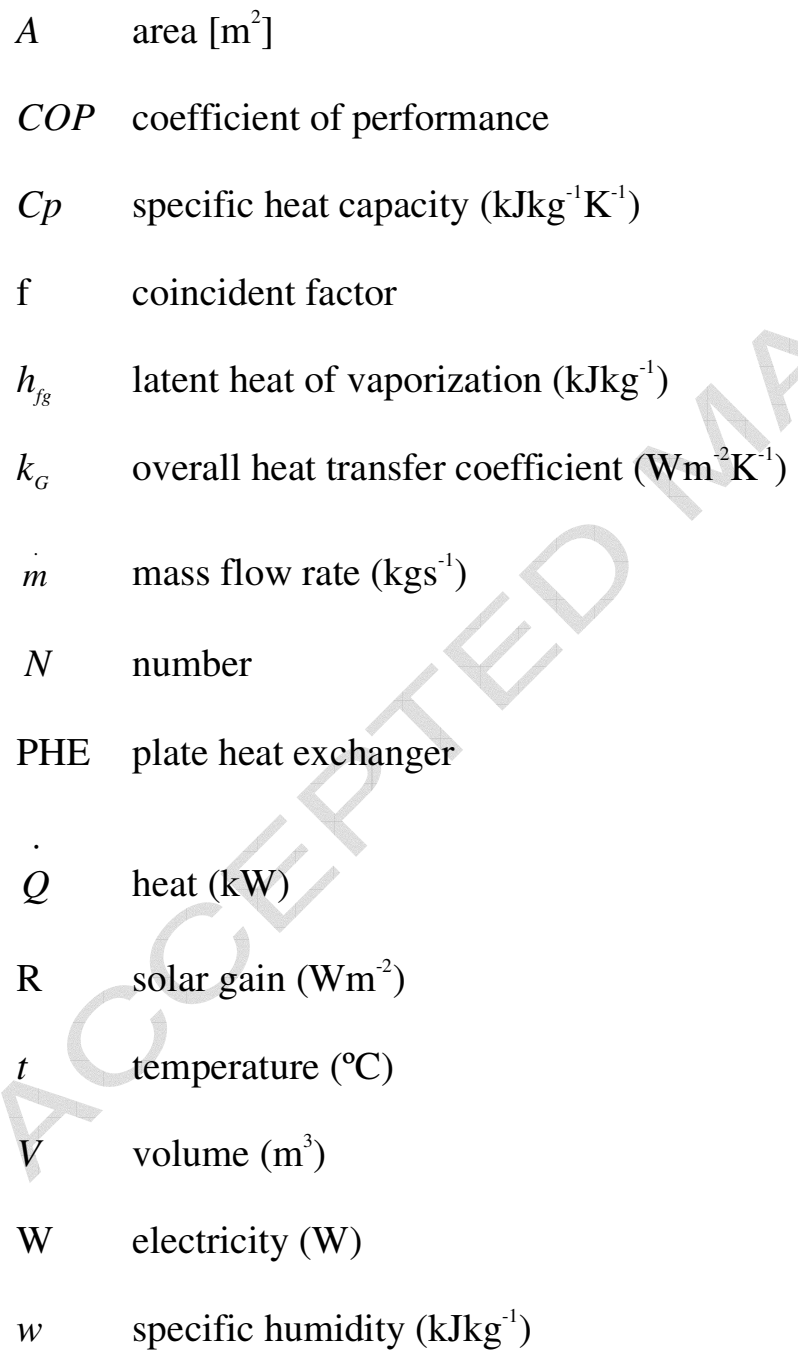

Subscripts 


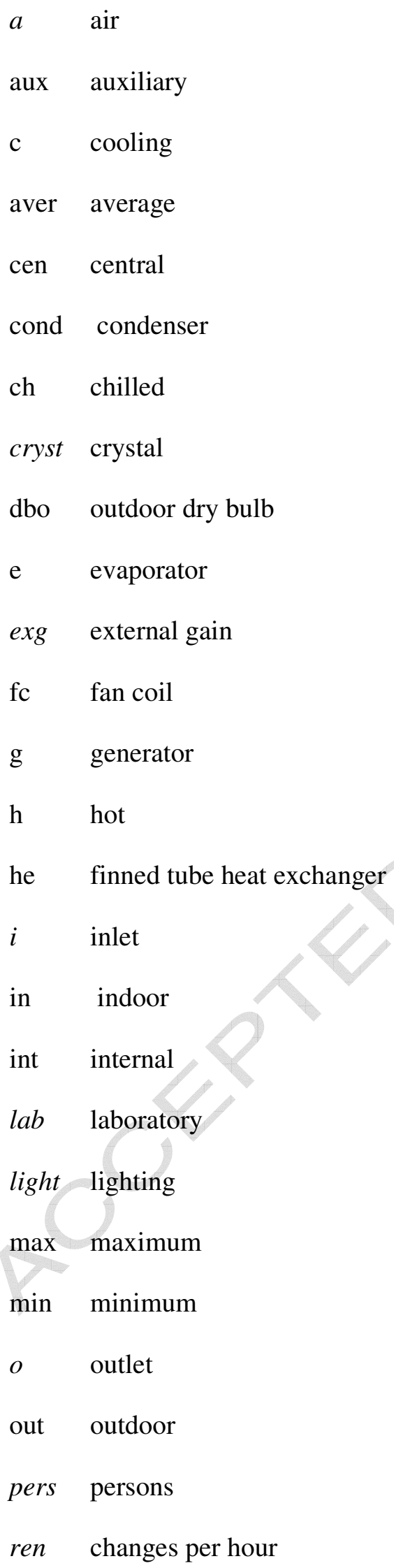




$\begin{array}{ll}\text { sec } & \text { security } \\ t & \text { thermal } \\ \text { trans } & \text { transmission } \\ \text { vent } & \text { ventilation } \\ w & \text { water }\end{array}$

Greek symbols density $\left(\mathrm{kgm}^{-3}\right)$

$\eta \quad$ efficiency

\section{Introduction}

Absorption and vapour compression technologies for space heating and cooling are based on the same principle: condensation and evaporation of a refrigerant. In compression systems the most common source of energy for the work required to compress the vapour is electricity, whereas in absorption systems it is heat, fed directly to the generator. The heat required may be provided by low pressure steam, residual heat, solar energy or directly from fossil fuel.

Single effect absorption machines, where the solution circulates in the generator at temperatures ranging from $70^{\circ} \mathrm{C}$ to $120^{\circ} \mathrm{C}$, may be air- or water-cooled. Watercooled facilities have been found to have two drawbacks: the risk of legionnaire's disease and, in residential areas, the difficulty of accommodating the equipment because it includes the cooling tower. In air-cooled systems where heat transfer is lower, higher condensation temperatures are reached, necessitating larger heat exchangers. Such systems are likewise subject to operational limits imposed by the risk of crystallization. 


\section{ACCEPTED MANUSCRIPT}

This obstacle has prompted the use of other solutions exhibiting higher resistance to crystallization [1].

The absorber is a key component in absorption chiller design for the impact of its performance on system efficiency, particularly when the ambient temperature is high. Substantial effort has been devoted to improving absorbers in recent years, in an attempt to reduce their size by optimizing heat and mass transfer. Film [2 - 6], drop [6 8] and bubble absorbers [9 - 11] as well as rotary absorption [12-13] have all been successfully used to this end.

M. Izquierdo et al. [14] proved that single effect absorption chillers are less efficient, in terms of primary energy, than air-cooled vapour compression facilities. Consequently, the former are unsatisfactory when fired with conventional fuel. They do constitute an alternative, however, at times of peak electricity demand when powered by solar energy. A. Syed et al. [15] studied the performance of a water-cooled single effect $\mathrm{LiBr}-\mathrm{H}_{2} \mathrm{O}$ absorption chiller using solar hot water as the source of heat. They found the technology to be more efficient in hot, dry climates with large variations in relative humidity and dry bulb temperature. M. Izquierdo et al. [16] studied an air-cooled double stage absorption system fitted with flat solar collectors to supply heat to the generator and compared the results to the performance of a water-cooled single effect absorption chiller. They found that the condensation temperature reached in the former was $53{ }^{\circ} \mathrm{C}$, whereas in the single effect chiller, in which heat was also supplied by flat solar collectors, condensation temperatures of over $45^{\circ} \mathrm{C}$ had to be ruled out due to solution crystallization.

F. Asdrubali et al. [17] conducted an experimental study with a water-cooled single effect absorption chiller in which the required heat was obtained from flat solar collectors. The maximum COP was obtained when the hot water temperature rose to $70{ }^{\circ} \mathrm{C}$, making this an appropriate technology for use with flat solar collectors as the 
source of energy. Until 2005, all the single effect absorption chillers on the market, such as those manufactured by Yazaki ${ }^{\circledR}$ and others, were water-cooled. Since that year, Rotartica® has been manufacturing air-cooled machines.

Trials were conducted in August 2005 to determine the highest outdoor dry bulb temperature for which the commercial (Rotartica 045v), air-cooled single effect $\mathrm{LiBr} / \mathrm{H}_{2} \mathrm{O}$ absorption chiller, is able to produce cool water for air conditioning use. The reader can find more information about the development and history of the machine in the references [13] and [18].

\section{Experimental set-up}

The chiller used and the experimental procedure followed are described below.

\subsection{Air-cooled single effect absorption chiller}

The Rotartica model 045v 4.5-kW chiller (Figure 1) is an indirect fired single effect system using $\mathrm{LiBr}-\mathrm{H}_{2} \mathrm{O}$ as the working fluid. The system is based on rotary absorption technology. Its main components are: the generator, evaporator and condenser-absorber unit, all installed inside a rotary drum. The drum rotates to improve the heat transfer by means of the generation of a turbulent flow in the $\mathrm{LiBr}$ solution.

The condenser-absorber unit is cooled by a water-air finned tube heat exchanger and a fan. Absorption takes place in a vacuum-sealed vessel. The nominal electric power is $1200 \mathrm{~W}$ and the volume $0.93 \mathrm{~m}^{3}$. It is designed for use in the service sector and residential and office buildings. 


\section{ACCEPTED MANUSCRIPT}

The external systems consists of a heat source and three water circuits: the hot and chilled water circuits, and the cooling water circuit for the condenser-absorber unit. A simplified diagram of the facility is given in Figure 2.

\subsection{Heat source circuit}

The heat source comprises a thermal oil tank with $10-\mathrm{kW}$ electrical resistances, a PHE and an AEG AM880KY4 pump. The thermal oil, heated by the resistances, is pumped to the PHE where it transfers heat to the water subsequently fed to the generator.

\subsection{Hot water circuit}

The water heated in the plate heat exchanger to a temperature of over $80{ }^{\circ} \mathrm{C}$ was delivered to the generator with the aid of a Grundfos UPS40-80R pump. In the generator, the heat from the hot water is used to separate the refrigerant by boiling the solution.

\subsection{Chilled water circuit}

The water chilled in the evaporator was delivered to the fan coil by a built-in pump. The purpose of the fan coil, a water-air heat exchanger placed inside the laboratory to be cooled, is to cool the indoor air with the chilled water from the evaporator.

\subsection{Cooling water circuit}


The heat is rejected to the environment through a water pump, finned tube heat exchanger and fan. The cooling water that cools the condenser and absorber is itself cooled in the heat exchanger, from which the absorption and condensation heat is driven by a fan to the outdoor atmosphere.

\subsection{Experimental procedure}

The experimental study was conducted at the Eduardo Torroja Institute Heat Pump Laboratory at La Poveda, Arganda, Madrid, between 1st and 20th of August 2005. Meteodata 285 weather station outdoor dry bulb temperatures $\left(\mathrm{t}_{d b o}\right)$ were used throughout.

PT100 sensors, with an accuracy of $\pm 0.1^{\circ} \mathrm{C}$, were positioned at component inlets and outlets to measure air and water temperatures, while three ultrasonic flowmeters were used to measure water flow in the facility. All pipes were insulated with $15-\mathrm{mm}$ thick fibreglass.

According to manufacturer specifications, hot, chilled and cooling water flow rates of over $101 / \mathrm{min}, 201 / \mathrm{min}$ and $251 / \mathrm{min}$, respectively, were required. The chiller began to refrigerate when demand was generated in the laboratory, the hot water temperature was higher than $80^{\circ} \mathrm{C}$ and the flow rates in the three water circuits were within manufacturer-specified operating ranges.

\section{Outdoor temperatures}

The daily outdoor dry bulb temperatures $t_{d b o}$ for the period studied are shown in Figure 3. The high for the period, $41.3^{\circ} \mathrm{C}$, was reached on $07 / 08 / 2005$. 


\section{ACCEPTED MANUSCRIPT}

Inasmuch as Madrid's summertime $\mathrm{t}_{\mathrm{dbo}} \mathrm{s}$ vary widely, from 25 to $41.3{ }^{\circ} \mathrm{C}$, three representative days were chosen for more detailed analysis. Fig. 4 shows the daily outdoor dry bulb temperatures recorded for the three days chosen, defined as follows:

- Warm, with temperatures under $30^{\circ} \mathrm{C}(10 / 08 / 05)$

- Hot, with temperatures between 30 and $36{ }^{\circ} \mathrm{C}(04 / 08 / 05)$

- $\quad$ Very hot, with temperatures between 36 and $41.3{ }^{\circ} \mathrm{C}(07 / 08 / 05)$

\section{Thermal load}

The space to be refrigerated, part of the Heat Pump Laboratory, has a net floorspace of $40 \mathrm{~m}^{2}$ and a volume of $120 \mathrm{~m}^{3}$. The thermal load $Q_{t}$ (Eq. (1)) was calculated from the energy balance set out in equations (2)-(5). These equations respectively define the transmission, air change, external heat gain and internal loads.

$Q_{t}=Q_{\text {trans }}+Q_{\text {vent }}+Q_{\text {exg }}+Q_{\text {in }}$

$Q_{\text {trans }}=k_{G} \cdot A_{\text {lab }} \cdot\left(t_{d b o}-t_{\text {ind }}\right)$

$Q_{\text {vent }}=V \cdot N_{\text {ren }} \cdot \rho_{a} \cdot C p_{a} \cdot\left(t_{d b o}-t_{i n d}\right)+V \cdot N_{r e n} \cdot \rho_{a} \cdot h_{f g} \cdot\left(w_{\text {out }}-w_{\text {ind }}\right)$

$Q_{\text {exg }}=A_{\text {cryst }} \cdot R$

$Q_{\text {in }}=Q_{\text {pers }} \cdot N_{\text {pers }} \cdot f+q_{\text {light }} \cdot A_{\text {light }}+Q_{\text {equip }} \cdot N_{\text {equip }}$

Thermal load, $Q_{t}$, was assumed to be generated only during working hours (9:00 a.m. to 8:00 p.m.) and when the temperature inside the laboratory was over $24^{\circ} \mathrm{C}$. The UA factor for the space to be refrigerated was $252 \mathrm{~W} / \mathrm{K}$. The space is occupied by three people for 10 hours a day. The coincident factor was assumed to be $\mathrm{f}=0.75$. 


\section{ACCEPTED MANUSCRIPT}

The thermal load observed for a comfortable indoor temperature of $24{ }^{\circ} \mathrm{C}$ at the maximum $\mathrm{t}_{\mathrm{dbo}}$ recorded $\left(42^{\circ} \mathrm{C}\right)$ was $5.5 \mathrm{~kW}$.

The demand for the three days selected is shown in Figure 5: $10.4 \mathrm{kWh}$ for 10/08/05; $40 \mathrm{kWh}$ for 04/08/05 and $50 \mathrm{kWh}$ for 07/08/05.

Figure 6 shows the demand for August calculated with equations (2) - (5). The total demand for the period was 1.49 MWh.

\section{Coefficient of Performance}

The coefficient of performance (equation 7) is defined to be the ratio between the heat removed by the evaporator and the energy supplied to the generator:

$C O P=\frac{Q_{e}}{Q_{g}}$

If the electric power used is included in the equation, COP is calculated as:

$C O P=\frac{Q_{e}}{Q_{g}+Q_{a u x}}$

$Q_{\text {aux }}=\frac{W}{\eta_{\text {cen }}}$

where $\mathrm{W}$ is the power demand corresponding to auxiliary equipment.

\section{Results and discussion}

The flow in each water circuit was held constant while the chiller was in operation. The values recorded for the hot, chilled and cooling water circuits were 0.28 


\section{ACCEPTED MANUSCRIPT}

$\mathrm{kg} / \mathrm{s}, 0.53 \mathrm{~kg} / \mathrm{s}$ and $0.67 \mathrm{~kg} / \mathrm{s}$, respectively, i.e., all within the manufacturer's specified operating range (Figure 7).

\subsection{Typical days}

The experimental results for the generator, the evaporator, the fan coil and the finned tube heat exchanger on the three days selected for the trial are set out below, together with the daily $C O P$.

- Warm day: 10/08/05

The air and water inlet and outlet temperatures recorded on the warm day in the generator, fan coil and finned tube heat exchanger, are given in Figure 8.

The hot water temperature in the generator ranged from $85^{\circ} \mathrm{C}$ to $99^{\circ} \mathrm{C}$, with a difference of approximately $5{ }^{\circ} \mathrm{C}$ between the inlet and outlet temperatures. These variations in the hot water inlet temperature in the generator, $t_{\text {iwg, }}$ affected the chilled water outlet temperature in the evaporator, $t_{\text {owe }}$.

At a dry bulb temperature of $26.7^{\circ} \mathrm{C}$, the chilling power found for the evaporator was $5.6 \mathrm{~kW}$. Figure 5 shows that the thermal load was consistently lower than $3 \mathrm{~kW}$ all day. Since the pipe running between the evaporator and the fan coil was insulated, $\mathrm{t}_{\text {owe }}$ and $t_{\text {iwc }}$ were assumed to be approximately equal. The inlet water temperature in the fan coil, $\mathrm{t}_{\mathrm{iwf}}$, and the inlet water temperature in the generator, $\mathrm{t}_{\mathrm{iwg}}$, were found to be inversely related. Moreover, for $\mathrm{t}_{\mathrm{dbo}}=26.7^{\circ} \mathrm{C}$ and $\mathrm{t}_{\mathrm{iwg}}=99^{\circ} \mathrm{C}$, $\mathrm{t}_{\text {iwfc }}$ was $12.7^{\circ} \mathrm{C}$ and $\mathrm{t}_{\text {owfc }}=14.8^{\circ} \mathrm{C}$.

At $t_{d b o}=26.7^{\circ} \mathrm{C}$, the cooling water inlet temperature in the finned tube heat exchanger was $36.9^{\circ} \mathrm{C}$ while the air temperature rose by approximately $9{ }^{\circ} \mathrm{C}$. 
- Hot day: 04/08/05

The air and water inlet and outlet temperatures recorded on the hot day in the generator, fan coil and finned tube heat exchanger are given in Figure 9.

The hot water temperature in the generator ranged from $91{ }^{\circ} \mathrm{C}$ to $105.4{ }^{\circ} \mathrm{C}$, with a difference of approximately $5{ }^{\circ} \mathrm{C}$ between the inlet and outlet temperatures. The generator temperatures rose as a result of the increase in the cooling water (absorbercondenser unit) temperatures.

At dry bulb temperatures of $28.9^{\circ} \mathrm{C}$ and $35.6^{\circ} \mathrm{C}$, the chilling power found for the evaporator came to 5.1 and $4.2 \mathrm{~kW}$, respectively. Figure 5 shows that the thermal load increased during the day, peaking at $4.5 \mathrm{~kW}$ between 15:00h and 18:00 $\mathrm{h}$ solar time. Figure 9 shows that $t_{\text {iwc }}$ rose with $Q_{t}$ and steadied when $Q_{t}$ stabilized. Moreover, for $\mathrm{t}_{\mathrm{dbo}}=28.9^{\circ} \mathrm{C}$ and $\mathrm{t}_{\mathrm{iwg}}=97^{\circ} \mathrm{C}$, $\mathrm{t}_{\mathrm{iwf}}$ was $14.9^{\circ} \mathrm{C}$ and $\mathrm{t}_{\mathrm{owfc}} 17.2^{\circ} \mathrm{C}$; and for $\mathrm{t}_{\mathrm{dbo}}=35.6^{\circ} \mathrm{C}$ and $\mathrm{t}_{\text {iwg }}=105.4^{\circ} \mathrm{C}, \mathrm{t}_{\text {iwf }}$ was $17.5^{\circ} \mathrm{C}$ and $\mathrm{t}_{\text {owf }} 19.4^{\circ} \mathrm{C}$. The indoor temperature in the laboratory remained constant at about $23.5^{\circ} \mathrm{C}$ throughout the day.

In the finned tube heat exchanger, at $\mathrm{t}_{\mathrm{dbo}}=35.6^{\circ} \mathrm{C}$, the cooling water inlet temperature was $45.6^{\circ} \mathrm{C}$, while the air temperature rose by approximately $9^{\circ} \mathrm{C}$.

- Very hot day: 07/08/05

The air and water inlet and outlet temperatures recorded on the very hot day in the generator, fan coil and finned tube heat exchanger are given in Figure 10. As this was the hottest day in the period studied, the condensation-absorption temperatures recorded were also the highest (Figure 10). The resulting rise in the solution temperature in the generator raised the hot water temperature from 86.5 to $107.2^{\circ} \mathrm{C}$, with a difference of approximately $5^{\circ} \mathrm{C}$ between the inlet and outlet temperatures. 


\section{ACCEPTED MANUSCRIPT}

At dry bulb temperatures of $28.6^{\circ} \mathrm{C}$ and $41.3^{\circ} \mathrm{C}$, the chilling power found for the evaporator came to 5.4 and $3.62 \mathrm{~kW}$, respectively. By 12:00 h solar time, $\mathrm{Q}_{\mathrm{t}}$ rose to 4.5 $\mathrm{kW}$, during which time $\mathrm{t}_{\mathrm{iwc}}$ also increased. Moreover, for $\mathrm{t}_{\mathrm{dbo}}=28.6^{\circ} \mathrm{C}$ and $\mathrm{t}_{\mathrm{iwg}}=94.5^{\circ} \mathrm{C}$, $\mathrm{t}_{\text {iwf }}$ was $17.3^{\circ} \mathrm{C}$ and $\mathrm{t}_{\text {owfc }} 19.5^{\circ} \mathrm{C}$. The indoor temperature in the laboratory remained constant at $25.5^{\circ} \mathrm{C} . \mathrm{Q}_{\mathrm{t}}$ continued upward after 12:00 h solar time, peaking at $5.5 \mathrm{~kW}$.

Between 12:00h and 18:00 h solar time, for $\mathrm{t}_{\mathrm{dbo}}=41.3^{\circ} \mathrm{C}$ and $\mathrm{t}_{\mathrm{iwg}}=104.1^{\circ} \mathrm{C}$, $\mathrm{t}_{\text {iwf }}$ was 25.8 ${ }^{\circ} \mathrm{C}$ and $\mathrm{t}_{\text {owf }} 26^{\circ} \mathrm{C}$. The indoor temperature in the laboratory was $29^{\circ} \mathrm{C}$.

At an outdoor dry bulb temperature of $41.3^{\circ} \mathrm{C}$, the cooling water inlet_temperature in the finned tube heat exchanger was $51.3^{\circ} \mathrm{C}$, while the air temperature rose by $8{ }^{\circ} \mathrm{C}$.

- Daily COP

The daily COPs on the 10th, the 4th and the 7th of August were respectively 0.64, 0.52 and 0.42 .

\subsection{Period overall}

The results for the entire experimental period are discussed below.

\subsubsection{Chilling power}

The experimental results for the evaporator are represented in Figure 11. For outdoor dry bulb temperatures of from 22.9 to $41.3{ }^{\circ} \mathrm{C}$, the chilling power values obtained ranged from 5.78 to $3.62 \mathrm{~kW}$. This downward trend in chilling temperature with rising dry bulb temperatures is clearly visible in the figure. 


\section{ACCEPTED MANUSCRIPT}

\subsubsection{Chilled water temperature}

The chilled water outlet temperatures in the evaporator are charted against $\mathrm{t}_{\mathrm{dbo}}$ in Figure 12.The temperature distribution shown in this figure was obtained with $\mathrm{t}_{\mathrm{iwg}}$ values of from 80 to $107^{\circ} \mathrm{C}$. The following may be deduced from the data set (231 points) plotted in Figure 12:

- $\quad$ For $\left(25.3^{\circ} \mathrm{C}<\mathrm{t}_{\mathrm{dbo}} \cdot 30^{\circ} \mathrm{C}\right) ; \mathrm{t}_{\text {owe }}>15^{\circ} \mathrm{C}$ for $18.2 \%$ of the data

- $\quad$ For $\left(30^{\circ} \mathrm{C}<\mathrm{t}_{\mathrm{dbo}} \cdot 35^{\circ} \mathrm{C}\right) ; \mathrm{t}_{\text {owe }}>15^{\circ} \mathrm{C}$ for $21.9 \%$ of the data.

- $\quad$ For $\left(35^{\circ} \mathrm{C}<\mathrm{t}_{\mathrm{dbo}}<41.3{ }^{\circ} \mathrm{C}\right) ; \mathrm{t}_{\text {owe }}>15^{\circ} \mathrm{C}$ for $81.4 \%$ of the data.

For example, the first case means that, for $25.3^{\circ} \mathrm{C}<\mathrm{t}_{\mathrm{dbo}}<30^{\circ} \mathrm{C}, \mathrm{t}_{\text {owe }}<15^{\circ} \mathrm{C}$ for $81.8 \%$ of the data.

The lowest chilled water temperature recorded, $11.3^{\circ} \mathrm{C}(22 / 08 / 2005)$, was found for an outdoor dry bulb temperature of $29,9^{\circ} \mathrm{C}$ and a $\mathrm{t}_{\text {iwg }}$ value of $100.5^{\circ} \mathrm{C}$. The chilling power was $4.67 \mathrm{~kW}$. Chilled water outlet temperatures ranged from 11.3 to $24.3^{\circ} \mathrm{C}$. The air flow rate needed to cover thermal demand increased with rising $t_{\text {owe }}$, which had an adverse effect on comfort.

\subsubsection{Energy balance}

The energy balance was calculated for the evaporator and generator. Heating and chilling power can be expressed as follows:

$Q_{g}=m_{w} \cdot C p_{w} \cdot\left(t_{i w g}-t_{\text {owg }}\right)$

$Q_{e}=m_{w} \cdot C p_{w} \cdot\left(t_{\text {iwe }}-t_{\text {owe }}\right)$ 
Daily values, which depend on the cooling demand, are shown in Figure 13.The heat supplied to the generator came to $\mathrm{Q}_{\mathrm{g}}=1085.5 \mathrm{kWh}$ and the heat removed in the evaporator to $\mathrm{Q}_{\mathrm{e}}=534.5 \mathrm{kWh}$.

\subsubsection{Seasonal coefficient of performance}

As Figure 14 shows, COP declined with increasing $\mathrm{t}_{\mathrm{dbb}}$. The value for the period as a whole was 0.49 .

While the chiller tested had $1200 \mathrm{~W}$ of electrical power at terminals, the value measured during the experiments was $900 \mathrm{~W}$. Water pumps and absorber-condenser fan electric consume during the period came to $112.5 \mathrm{kWh}$. On the grounds of this electric demand, $Q_{a u x}$, and of the overall generating efficiency of the Spanish electricity system, $\eta_{c e n}=0.33, \mathrm{COP}$ was computed to be 0.37 .

\section{Results in other regions}

The $t_{\mathrm{dbo}}$ values for the 4 th, the 7 th and the 10th of August used in the present study were recorded in a town a few miles southeast of Madrid. Such values are likewise representative of summer temperatures in other regions of Spain, however. The 10th and the 4th of August outdoor dry bulb temperatures, for instance, can also be found on different dates in cities like Vigo, Mallorca and Cadiz.

Consequently, the results found for typical summer days in Madrid can be extrapolated to other cities with a similar climate. 


\section{Conclusions}

Experimental research was conducted to determine the performance of a $4.5-\mathrm{kW}$ air-cooled chiller, single effect $\mathrm{LiBr} / \mathrm{H}_{2} \mathrm{O}$ absorption unit. (Rotartica 045v) The experiments were run at the Eduardo Torroja Institute Heat Pump and Absorption Chiller Laboratory at La Poveda, Arganda del Rey, Madrid, in August 2005. Measurements were recorded over a 20-day period. The hot water inlet temperature in the generator varied throughout the day from $80{ }^{\circ} \mathrm{C}$ to $107^{\circ} \mathrm{C}$. Daily and period energy flows are given, along with the energy balance for the facility.

The total energy supplied to the generator came to $1085.5 \mathrm{kWh}$ and the heat removed in the evaporator to $534.5 \mathrm{kWh}$. The average COP for the period as a whole was 0.49 . When the electric power used by auxiliary equipment was factored into the equation, primary energy based COP came to 0.37 . The results obtained for Madrid can be extrapolated to other regions of Spain with $\mathrm{t}_{\mathrm{dbo}}$ s lower than $35^{\circ} \mathrm{C}$.

\section{Acknowledgements}

This study was funded by the National Research Plan 2005-2007, under Research Project ENE 2005-08255-CO2-01. The authors wish to express their gratitude to the I+D+i technician of IETcc Mr.Emilio Martín because without his contribution, this work would have never been possible.

\section{References}


[1] J. Yoon, O.Kwon, Cycle analysis of air-cooled absorption chiller using a new working solution, Energy 24 (1999) 795-809.

[2] W. Miller, H. Perez-Blanco, Vertical-tube aqueous LiBr falling film absorption using advanced surfaces, AES-Vol.31, in: Proceedings International Absorption Heat Pump Conference, ASME, 1994. pp.185-202.

[3] H. Tsuda, H. Perez-Blanco, An experimental study of a vibrating screen as jeans of absorption enhancement, International Journal of Heat and Mass Transfer 44. (2001) 4087- 4094.

[4] J. Killion, S. Garimella, A critical review of models of coupled heat and mass transfer in falling-film absorption, International Journal of Refrigeration 24 (2001) 775-797.

[5] S. Garimella, Miniaturized heat and mass transfer technology for absorption heat pumps ISHPPC'99, in: Proceedings of the International Sorption Heat Pump Conference, Munich, Germany, 1999, pp. 661-670.

[6] F. Warnakulasuriya, W. Worek, Adiabatic water absorption properties of an aqueous absorbent at very low pressures in a spray absorber, International Journal of Heat and Mass Transfer 49 (2006) 1592-1602.

[7] G. Orian, M.Jelinek, A.Levy, Spray formation of binary organic solution for an absorption refrigeration system, Applied Thermal Engineering 26 (2006) 872-880.

[8] W. Ryan, F. Ruiz, J. Wurm, Model development and verification of spray absorption for gas driven cooling systems, in: Proceedings of International Gas Research Conference, Cannes, 1995, pp. 1483-1493. 


\section{ACCEPTED MANUSCRIPT}

[9] H.M Sabir, I.W.Eames, K.O. Suen, The effect of non-condensable gases on the performance of film absorbers in vapour absorption systems, Applied Thermal Engineering 19 (1999) 531-541.

[10] Y. Kang, A. Akisawa, T. Kashiwagi, Analytical investigation of two different absorption modes: falling film and bubble types, International Journal of Refrigeration 23 (2000) 430-443.

[11] J. Cao, R. Christensen, Non-spherical bubble collapse mechanics in binary solutions, International Journal of Heat and Mass Transfer 44 (2001) 14111423

[12] Technical page Rotartica, http://www. rotartica.com

[13] K. Gilchrist, R. Lorton, R.J. Green, Process intensification applied to an aqueous $\mathrm{LiBr}$ rotating absorption chiller with dry heat rejection, Applied Thermal Engineering 22 (2002) 847-854.

[14] M. Izquierdo, P. Rodríguez, A. Lecuona, E. Martín, Energetic, economic and environmental viability of absorption air - conditioning systems in Spain. IEA Heat Pump Center Newsletter 16 (1998) 24-25

[15] A. Syed, M. Izquierdo, P. Rodríguez, G. Maidment, J. Missenden, A. Lecuona, R. Tozer., A novel experimental investigation of a solar cooling system in Madrid, International Journal of Refrigeration 28 (6) (2005) 859-871.

[16] M. Izquierdo, M. Venegas, P. Rodríguez, A. Lecuona, Crystallization as a limit to develop solar air-cooled $\mathrm{LiBr}-\mathrm{H}_{2} \mathrm{O}$ absorption systems using low-grade heat, Solar Energy Materials \& Solar Cells 81 (2004) 205-216.

[17] F. Asdrubali, S. Grignaffini, Experimental evaluation of the performances of a $\mathrm{H}_{2} \mathrm{O}-\mathrm{LiBr}$ absorption refrigerator under different service conditions, International Journal of Refrigeration 28 (2005) 489-497.

[18] http://www.rotartica.com. 


\section{ACCEPTED MANUSCRIPT}

Fig .1 Rotartica 045v.

Fig. 2. Scheme of heat source and interior of the machine.

Fig. 3. Maximum, average and minimum daily dry bulb outdoor temperatures on August 2005.

Fig. 4. Dry bulb outdoor temperature for three days selected of August

Fig. 5. Thermal load for the three characteristic days.

Fig. 6. Daily demand of August

Fig. 7. Flow rates corresponding to hot, cooling and chilled water loop.

Fig. 8. Left scale: Inlet and outlet temperatures in the generator. Right scale: fancoil and finned tubes heat exchanger (10/08/05).

Fig. 9. Left scale: Inlet and outlet temperatures in the generator. Right scale: fancoil and finned tubes heat exchanger (04/08/05).

Fig. 10. Left scale: Inlet and outlet temperatures in the generator. Right scale: fancoil and fin tubes heat exchanger $(07 / 08 / 06)$.

Fig. 11. Chilling power and dry bulb outdoor temperature

Fig. 12. Outlet chilled water temperature in the evaporator

Fig. 13. Heat supplied to the generator and cold produced in the evaporator.

Fig. 14. COP as a function of dry bulb outdoor temperature. 


\section{ACCEPTED MANUSCRIPT}

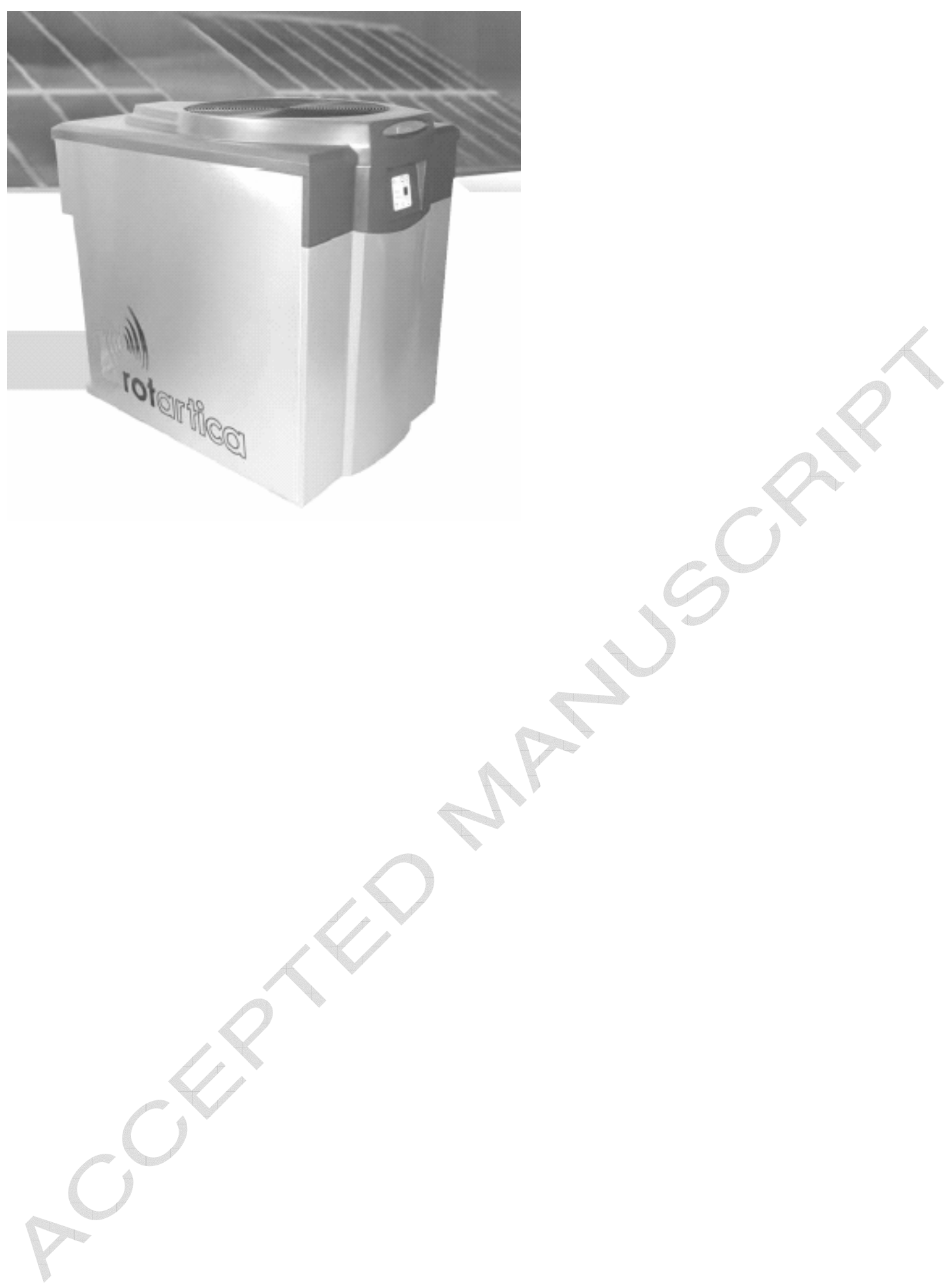




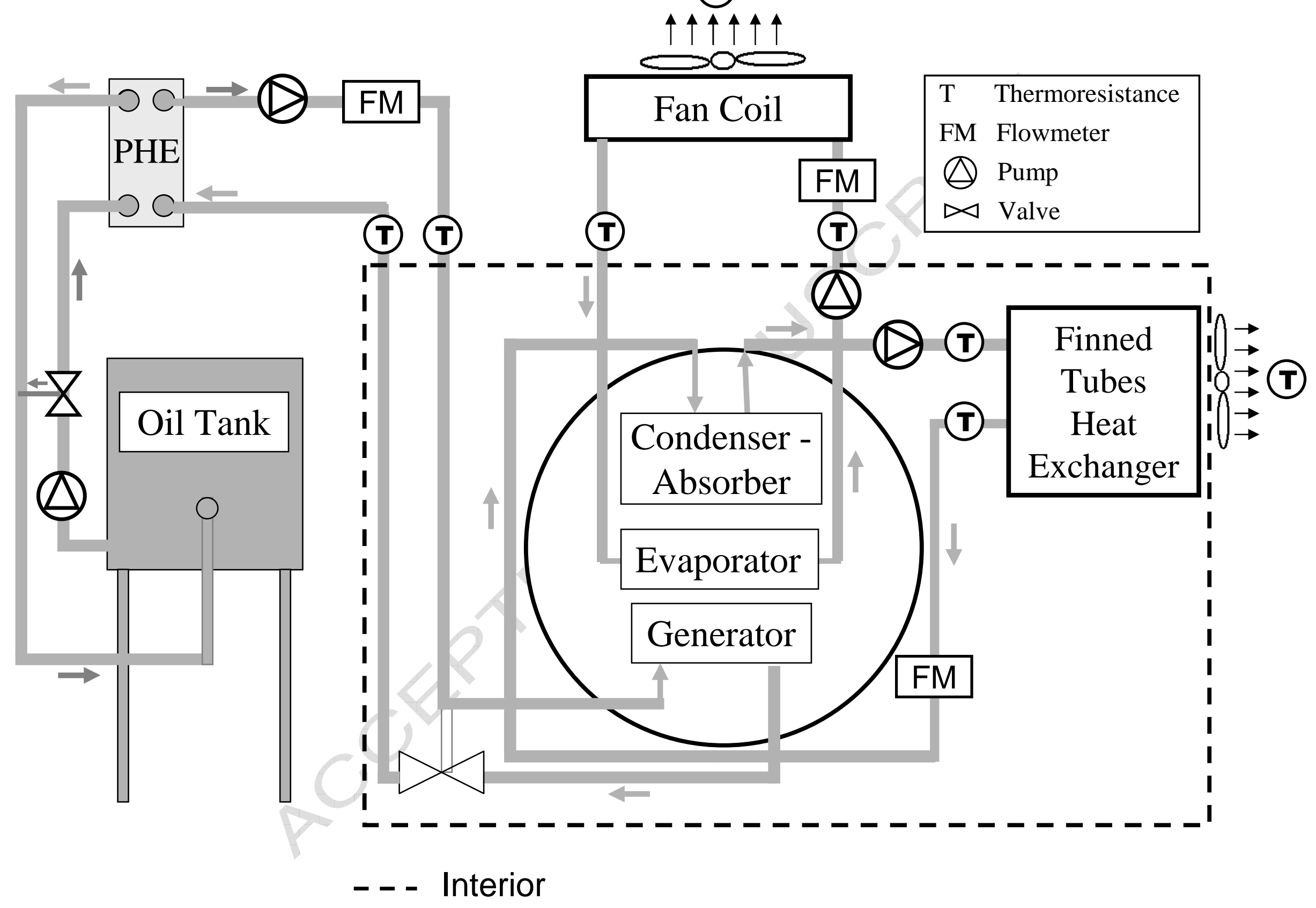




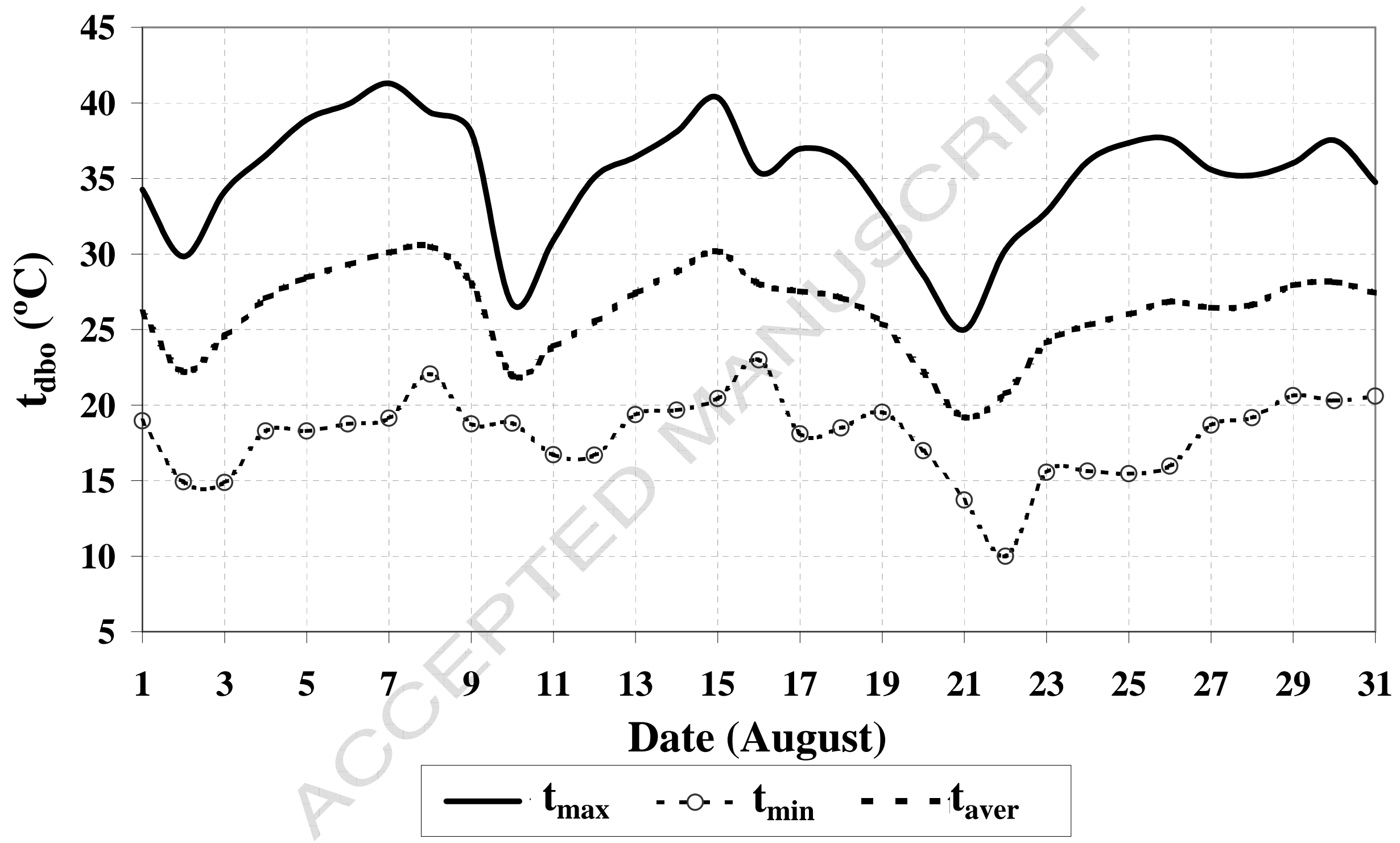




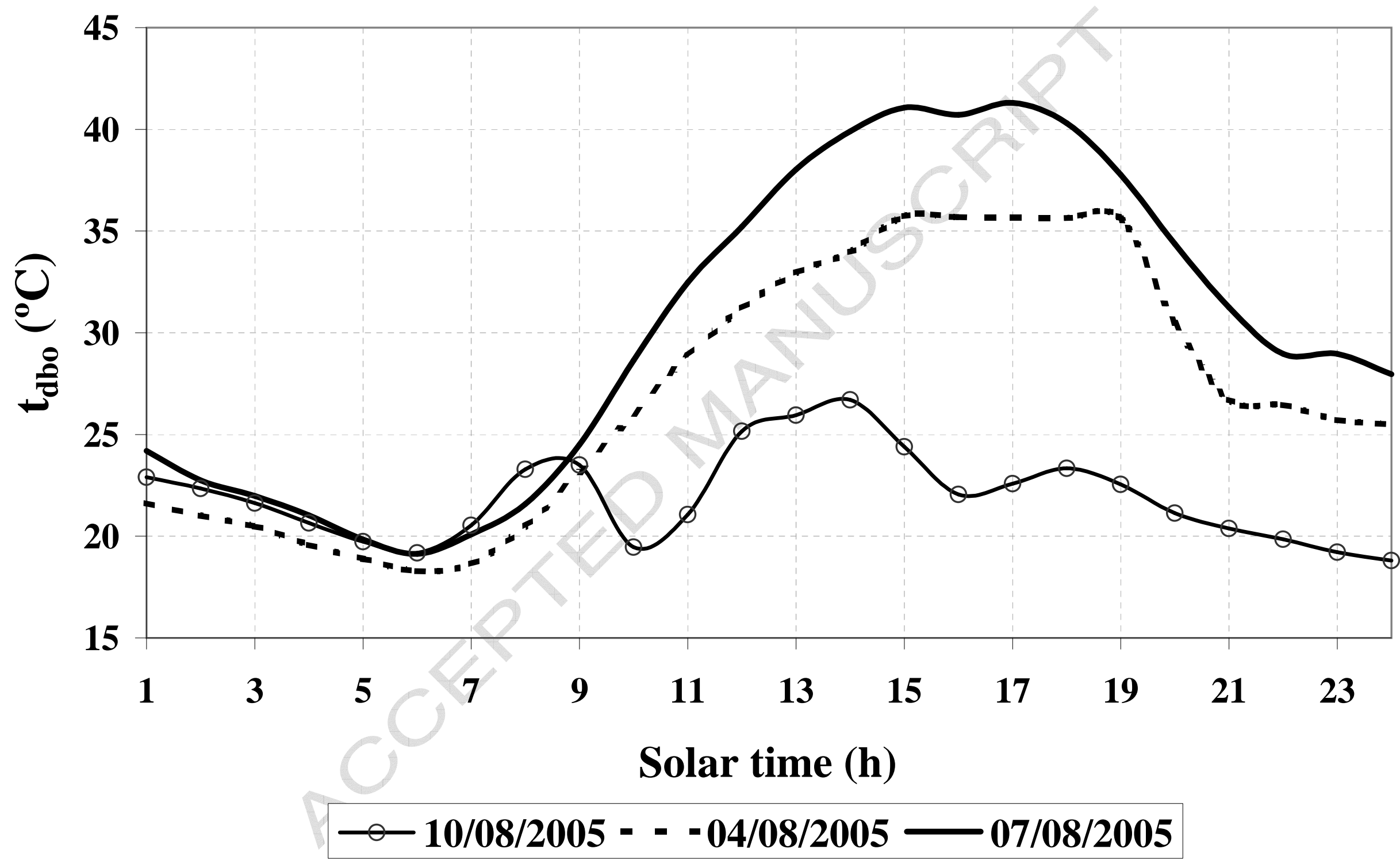




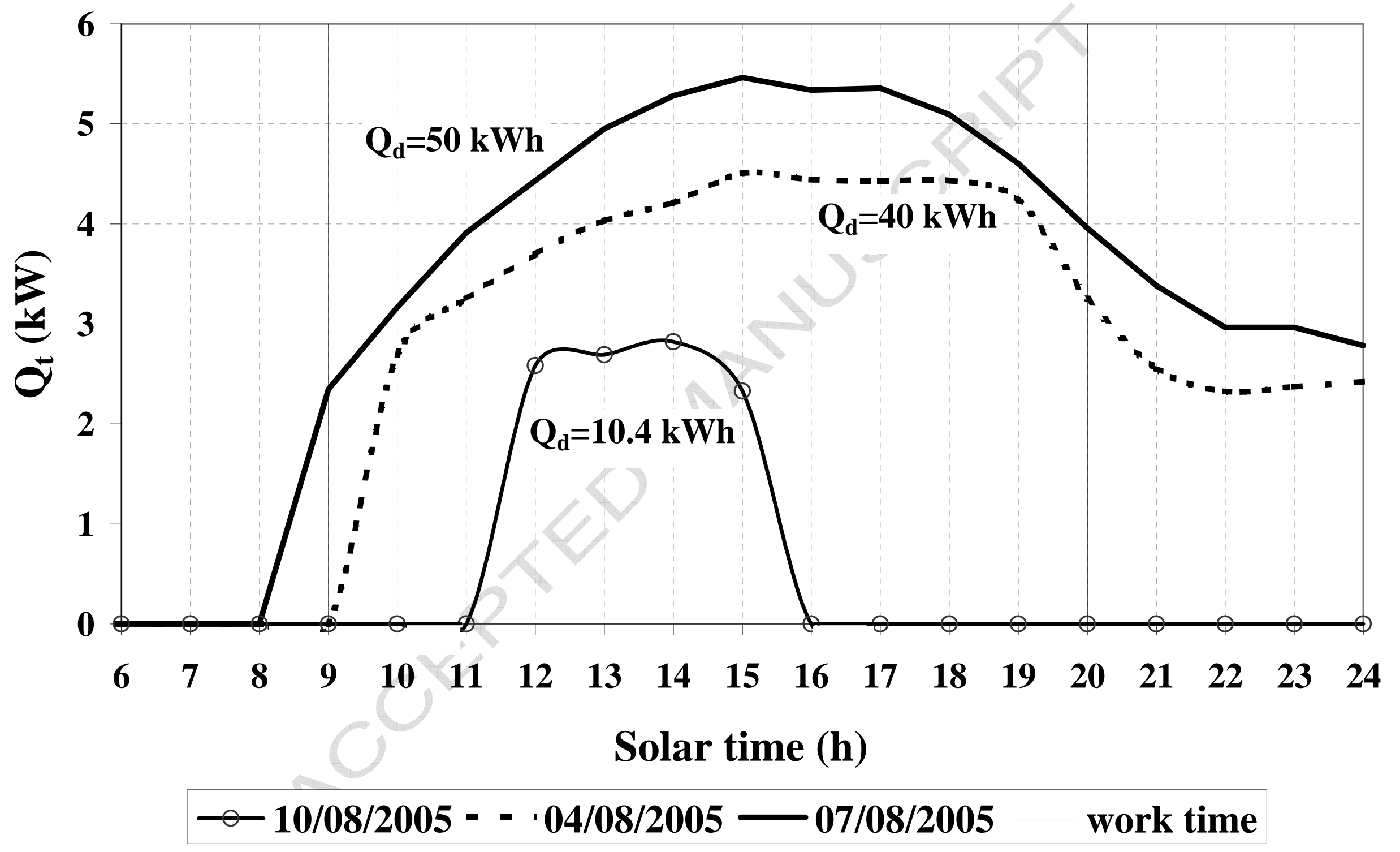




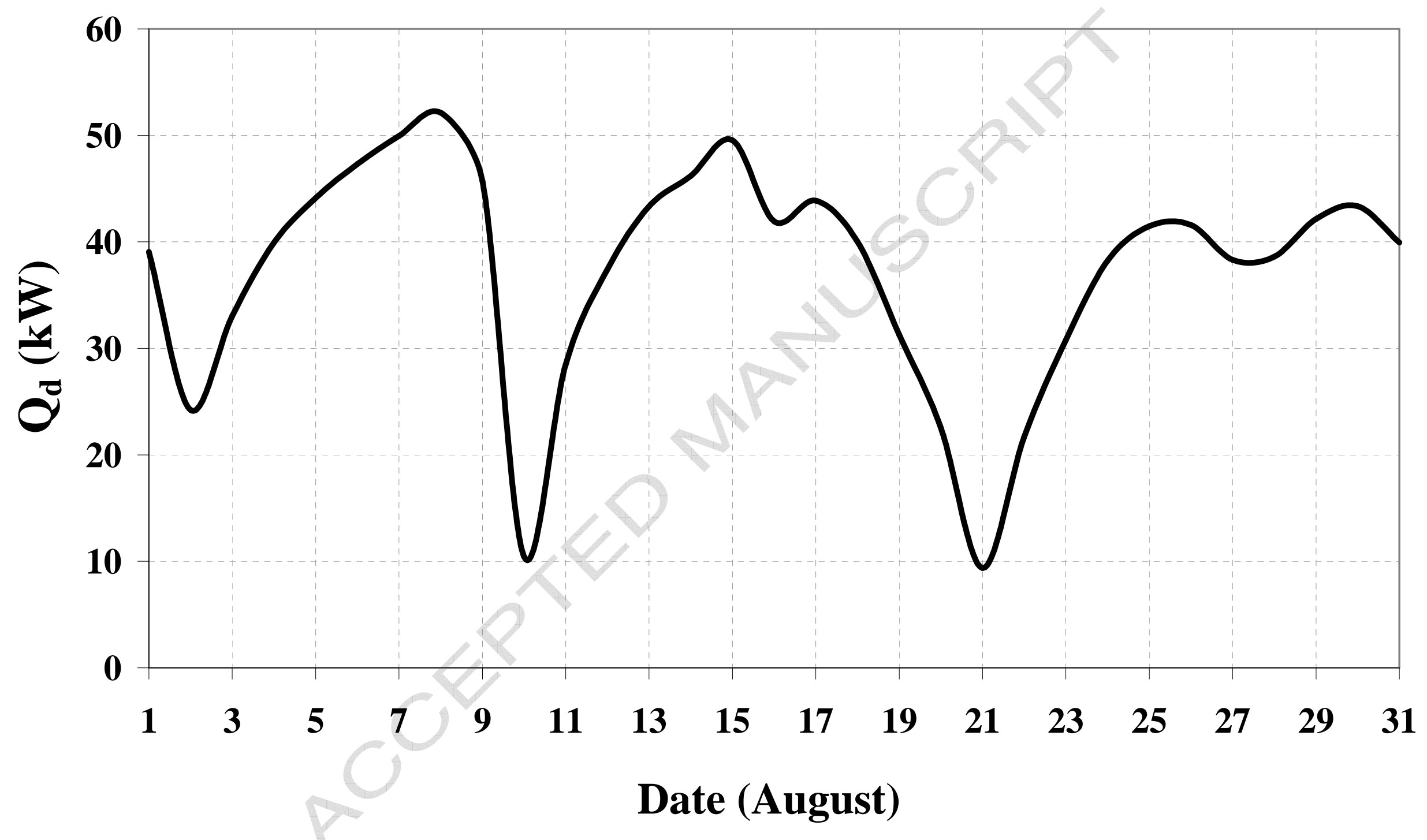




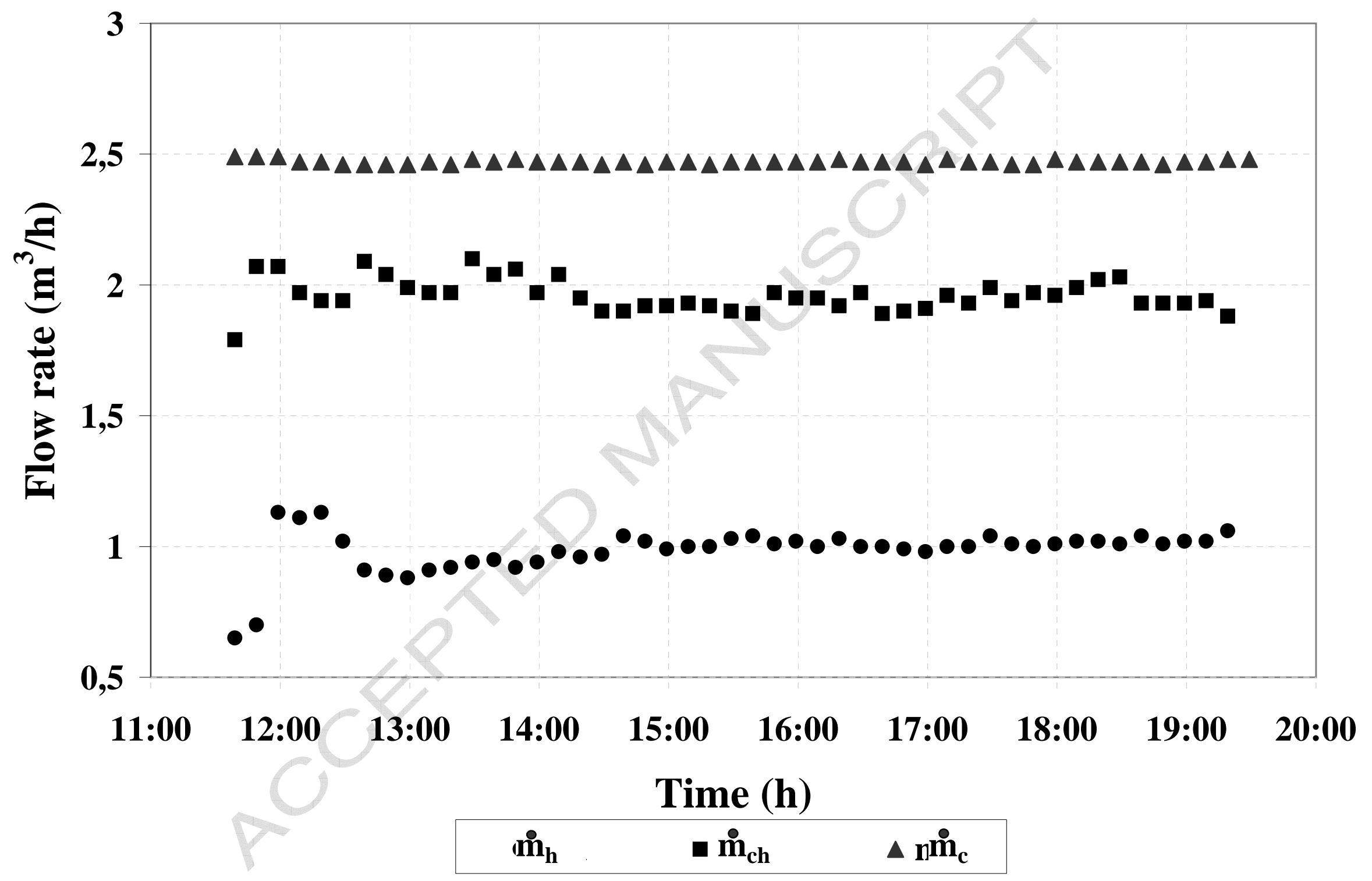




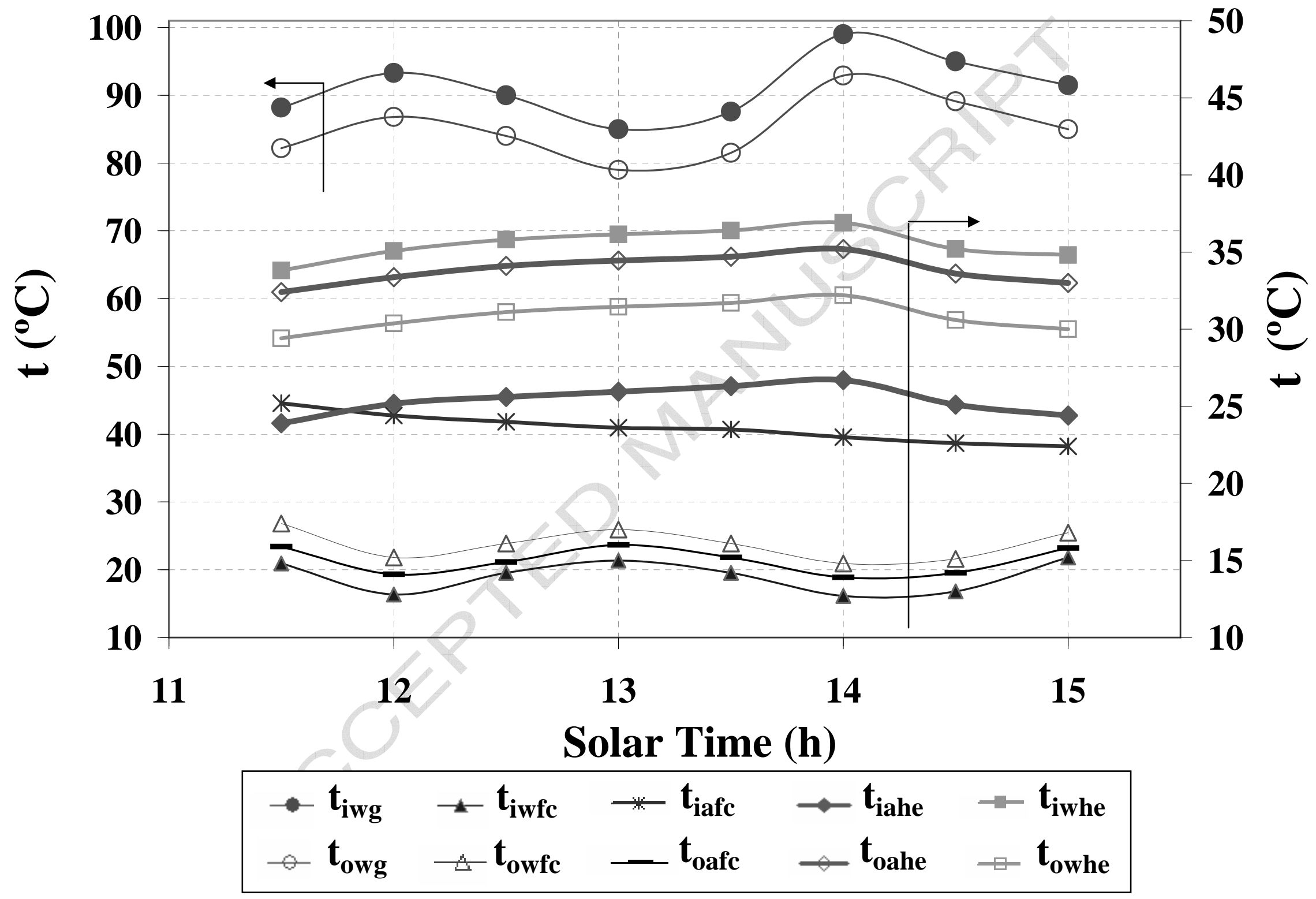




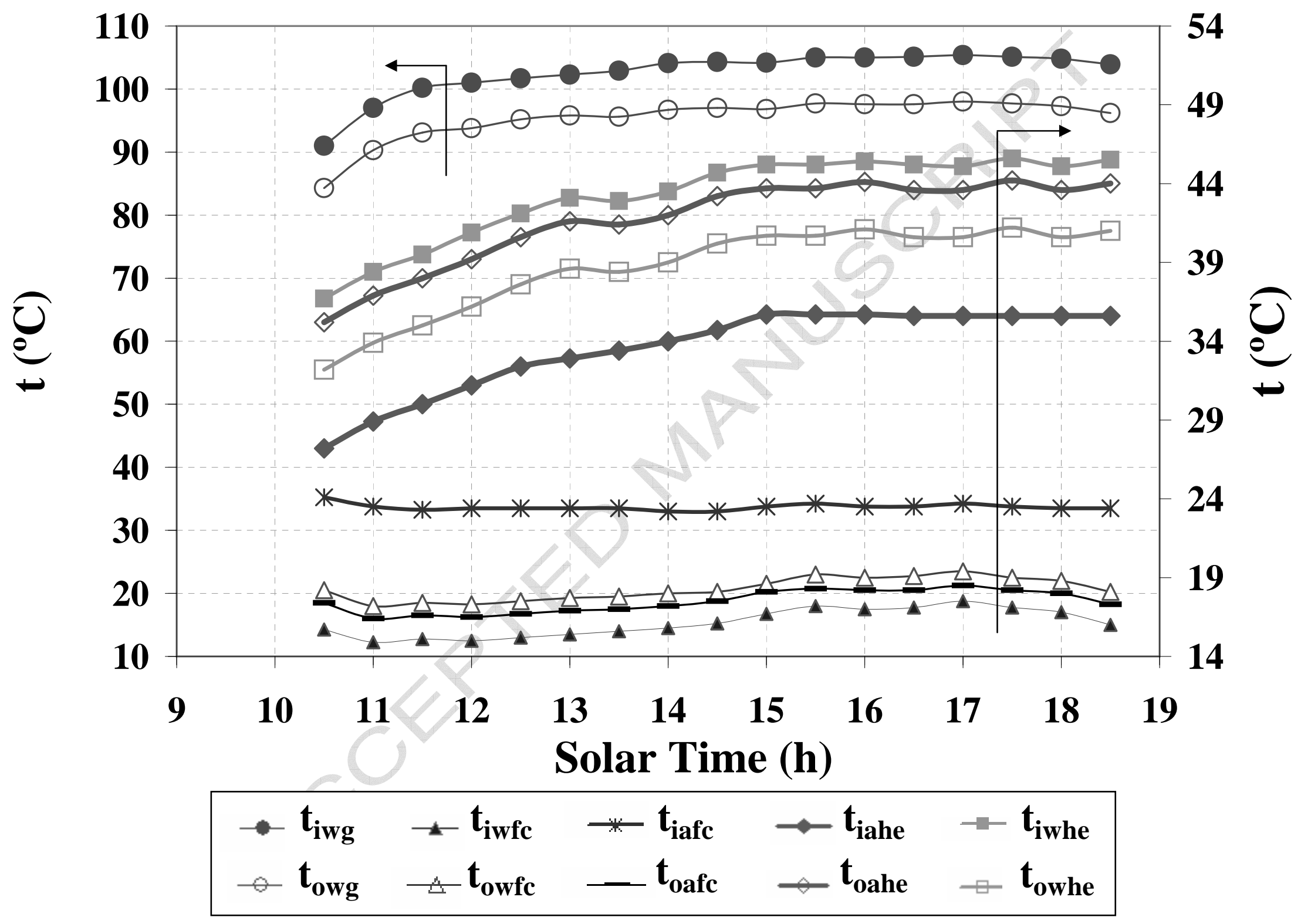




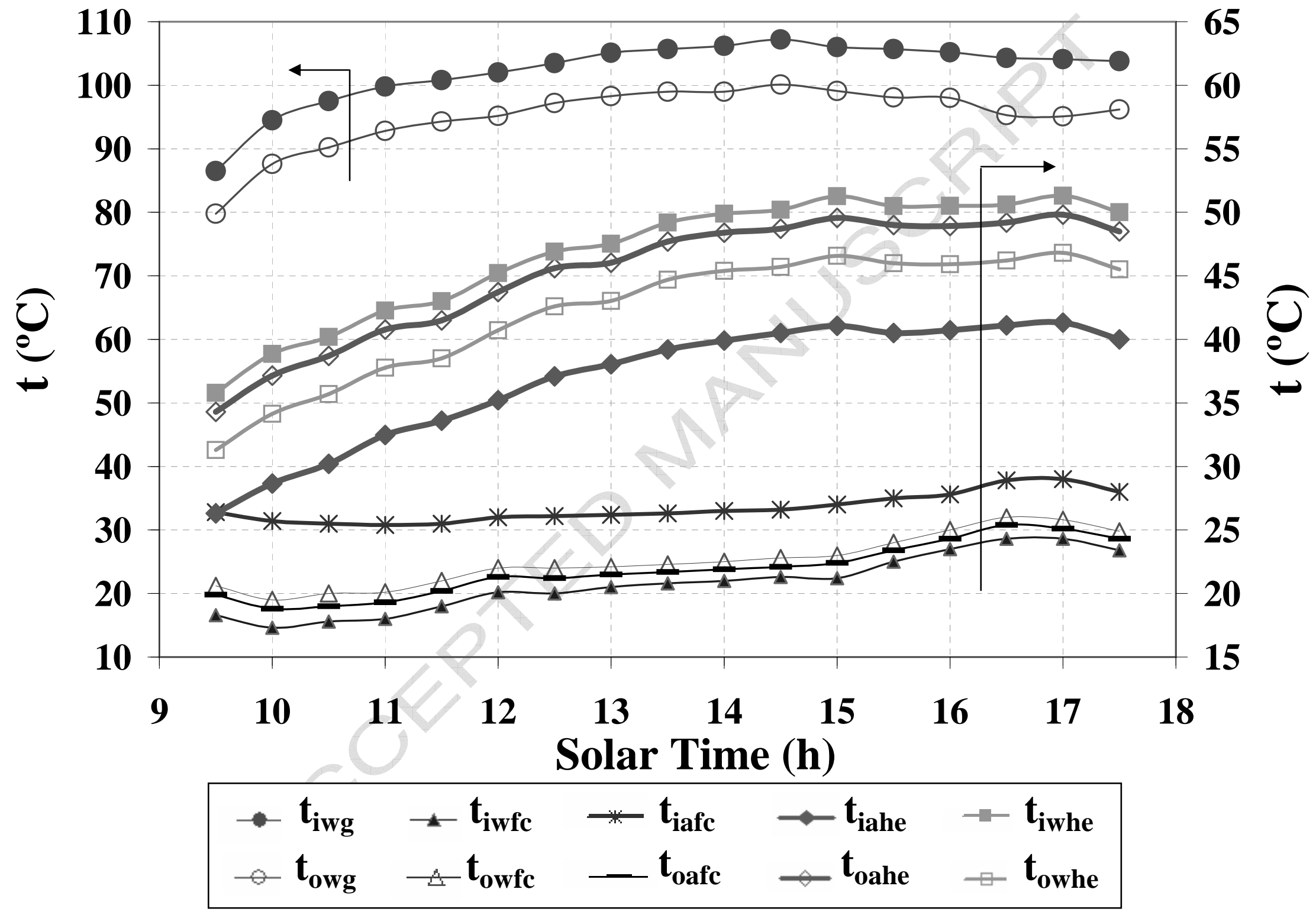




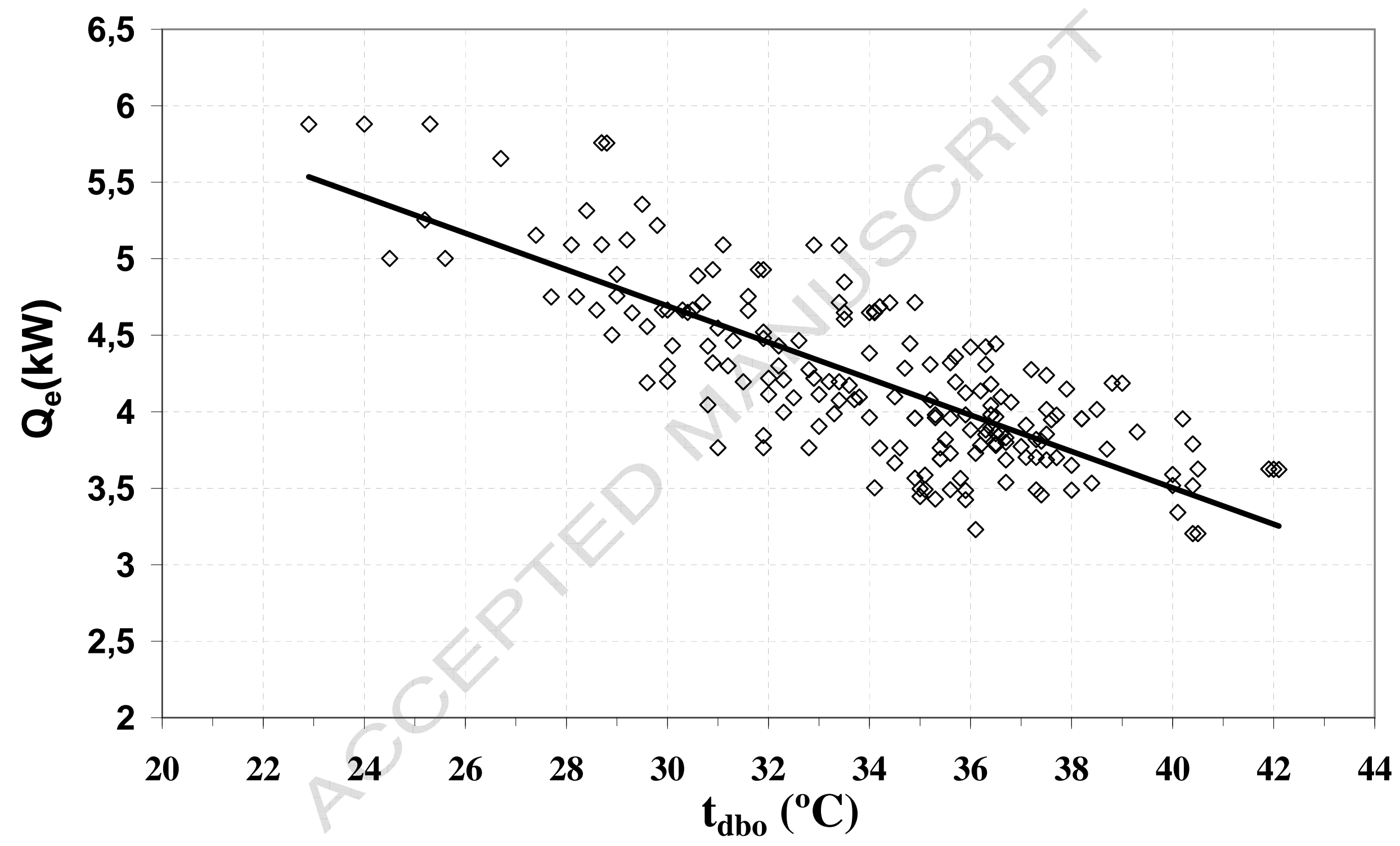




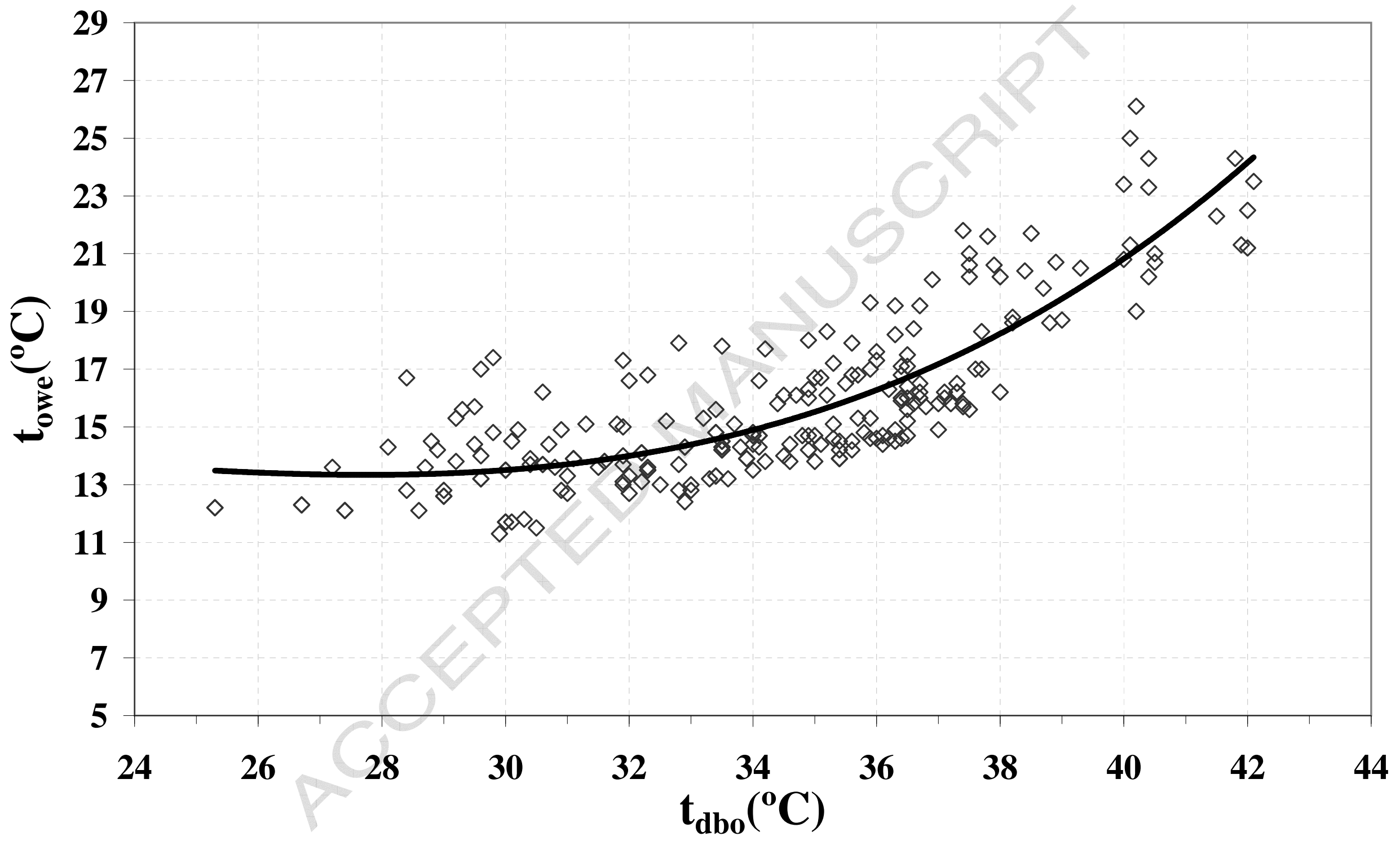




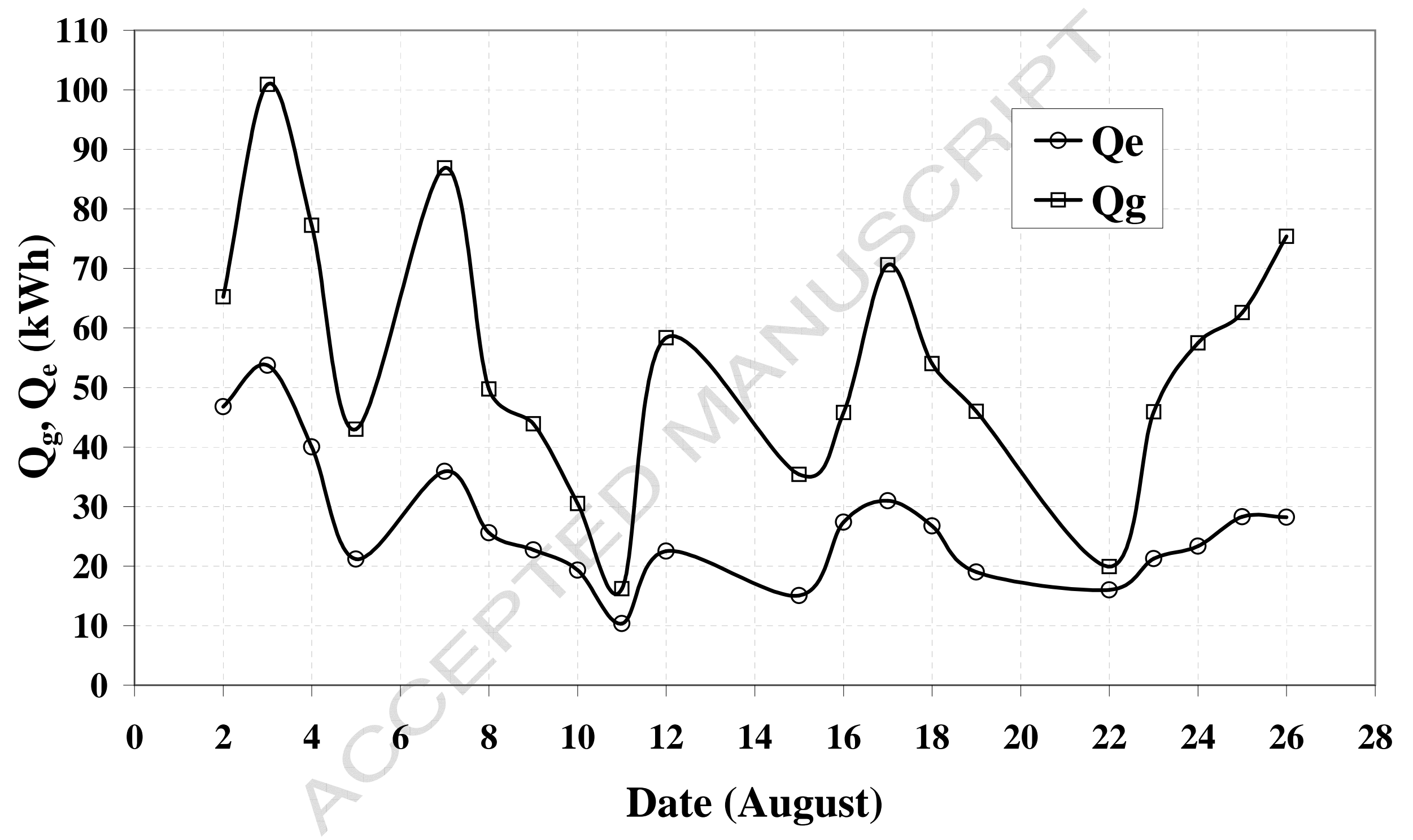




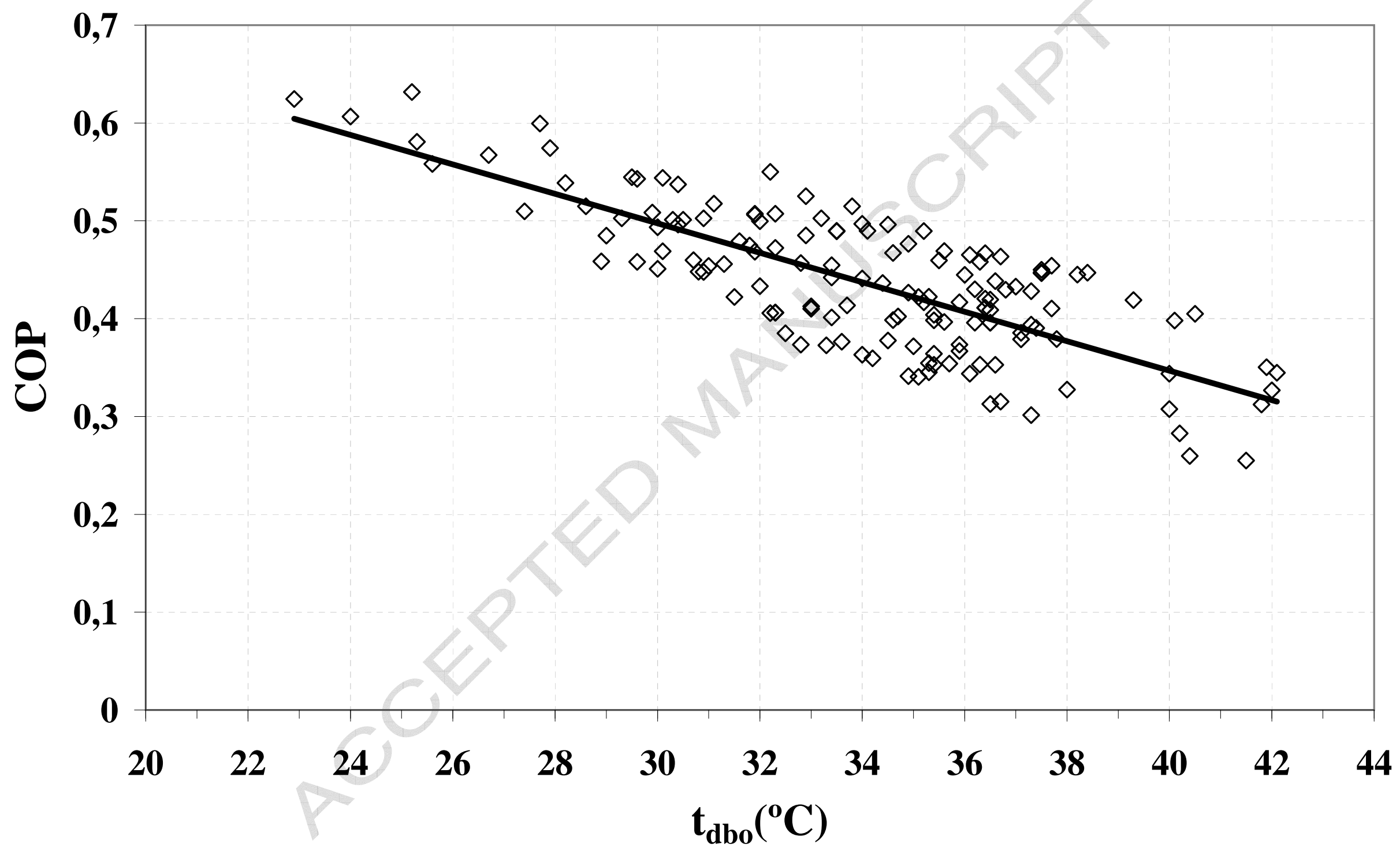

